\title{
TINJAUAN PENYALAHGUNAAN DANA DESA OLEH KEPALA DESA DI WILAYAH KEPOLISIAN RESOR WAJO
}

\author{
Review of Village Fund Misuse by The Heads of Villages in Wajo Police Area \\ Syarifuddin $^{1}$, Ruslan Renggong ${ }^{2}$, Baso Madiong ${ }^{2}$ \\ ${ }^{1}$ Magister Ilmu Hukum Program Pascasarjana Universitas Bosowa \\ ${ }^{2}$ Program Studi Ilmu Hukum Program Pascasarjana Universitas Bosowa \\ Email: syarifuddin66@gmail.com
}

Diterima: 01 Agustus 2020/Disetujui: 05 Desember 2020

\begin{abstract}
ABSTRAK
Tujuan penelitian ini adalah untuk mengetahui dan menganalisis penegakan hukum terhadap penyalahgunaan dana desa oleh kepala desa di wilayah Polres Wajo dan untuk mengetahui dan menganalisis faktor-faktor yang mempengaruhi efektivitas penegakan hukum terhadap penyalahgunaan dana desa oleh kepala desa di wilayah Polres Wajo. Tipe penelitian ini adalah penelitian deskriptif dengan pendekatan yuridis-empiris Penelitian ini dilaksanakan di Kabupaten Wajo yaitu tepatnya di Polres Wajo. Populasi dalam penelitian ini, antara lain: seluruh warga desa di Wilayah Polres Wajo. Sampel dalam penelitian ini ditentukan sebanyak 50 orang responden dengan menggunakan teknik purposive sampling Jenis data yang diperlukan dalam penelitian ini adalah data primer dan data sekunder. Metode pengumpulan data yang digunakan adalah melalui wawancara, dokumentasi dan kuesioner (angket). Analisis data menggunakan metode analisis kualitatif dan kuantitatif. Hasil Penelitian menunjukkan bahwa; Penegakan hukum terhadap penyalahgunaan dana desa oleh kepala desa di Wilayah Polres Wajo sudah dilaksanakan sesuai peraturan perundang-undangan yang berlaku. Sementara faktor substansi hukum, struktur hukum, sarana dan prasarana, budaya hukum, kesadaran hukum, dan biaya operasional berpengaruh terhadap efektifitas penegakan hukum penyalahgunaan dana desa oleh kepala desa di wilayah Polres Wajo, antara lain: substansi hukum, struktur hukum, sarana dan prasarana, budaya hukum, kesadaran hukum, dan biaya operasional.
\end{abstract}

Kata Kunci : Tinjauan Yuridis, Dana Desa, Kepala Desa, Resor Wajo

\begin{abstract}
The purpose of this study was to determine and analyze law enforcement on misuse of village funds by the village heads in Wajo Police area and to identify and analyze the factors that influence the effectiveness of law enforcement on misuse of village funds by the village heads in the Wajo Police area. This type of research is a descriptive study with a juridicalempirical approach. This research was conducted in Wajo Regency, which is precisely at Wajo Police Station. The population in this study included: all villagers in the Wajo Police Area. The samples in this study were 50 respondents determined by using purposive sampling techniques. The type of data needed in this study are primary data and secondary data. Data collection methods used were through interviews, documentation and questionnaires. Data analysis used was qualitative and quantitative analysis methods. Research shows that; Law enforcement against the misuse of village funds by the village heads in the Wajo Police Area has been carried out in accordance with applicable laws and regulations. Meanwhile the factors of legal substance, legal structure, facilities and infrastructure, legal culture, legal awareness, and operational costs affect the effectiveness of law enforcement of village fund misuse by the village heads in the Wajo Police Area, such as: legal substance, legal structure, facilities and infrastructure, legal culture, legal awareness, and operational costs.
\end{abstract}

Keywords: Juridical Overview, Village Fund, Village Heads, Wajo Resort

\section{PENDAHULUAN}

Desa merupakan representasi dari kesatuan masyarakat hukum terkecil yang telah ada dan tumbuh berkembang seiring dengan sejarah kehidupan masyarakat Indonesia dan menjadi bagian yang tidak terpisahkan dari tatanan kehidupan bangsa Indonesia. Sebagai wujud pengakuan Negara terhadap Desa, khususnya dalam rangka memperjelas fungsi dan kewenangan desa, serta memperkuat kedudukan desa dan masyarakat desa sebagai subyek pembangunan, diperlukan kebijakan penataan dan pengaturan mengenai desa yang diwujudkan dengan lahirnya Undang-Undang Nomor 6 Tahun 2014 tentang Desa. 
Undang-Undang No. 6 Tahun 2014 tentang Desa sudah mengatur desa sesuai dengan UUD 1945 dengan menempatkan desa berkedudukan di wilayah Kabupaten/Kota, yang diakui dan dihormati dalam Sistem Pemerintahan Negara Kesatuan Republik Indonesia. Tujuan diberlakukan Undang-Undang Desa tersebut, antara lain: (1) memberikan pengakuan dan penghormatan atas desa yang sudah ada dengan keberagaman sebelum dan sesudah terbentuk NKRI; (2) melestarikan dan memajukan adat, tradisi, dan budaya masyarakat desa, dan memperkuat masyarakat desa sebagai subjek pembangunan (Andi Hamzah, 2015).

Kepala desa merupakan pemimpin masyarakat disuatu desa guna menjalankan kewenangannya disuatu wilayah yang terdiri dari beberapa dusun. Mulai menjabatnya seorang kepala desa didasarkan pada pemilihan langsung oleh masyarakat desa di wilayah tertentu dengan waktu jabatan selama enam tahun. Kepala desa dipilih oleh masyarakat langsung, masyarakat seharusnya memilih berdasarkan pada pengetahuan calon kepala desa dalam menjalankan administrasi desa dan prilaku terhadap masyarakat (Bagir Manan, 2013). Pada umumnya yang terpilih menjadi kepala desa adalah orang-orang yang mempunyai kemampuan interaksi sosial yang baik, seperti tokoh adat, tokoh agama dan orang kaya, Interaksi sosial itu dilakukan kepada warganya. Sehingga kepala desa terpilih nantinya bukanlah orang yang mempunyai sumber daya manusia yang cukup dalam menjalankan pemerintahan desa.

Seiring dengan diberlakukannya Undang-Undang Nomor 6 Tahun 2014 tentang Desa yang diundangkan pada tanggal 15 Januari 2014 dan Peraturan Pemerintah Nomor 43 Tahun 2014 tentang Peraturan Pelaksanaan UndangUndang Nomor 6 Tahun 2014 tentang Desa yang diundangkan pada tanggal 30 Mei 2014, kemudian diterbitkan Peraturan Pemerintah Republik Indonesia Nomor 47 Tahun 2015 tentang Perubahan Atas Peraturan Pemerintah Nomor 43 Tahun 2014 Tentang Pelaksanaan Undang-Undang No. 6 Tahun 2014 tentang Desa. Keberadaan peraturan perudang-undangan tersebut memberikan pemahaman tentang pentingnya penyelenggaraan Pemerintahan Desa yang baik. Oleh karena itu, desa menjadi primadona dan menjadi fokus perhatian setelah terbitnya Undang-Undang Nomor 6 Tahun 2014 tentang Desa, karena desa adalah basis terkecil sebuah demokrasi asli sehingga perlu asas kehati-hatian, dalam pengelolaan dan penataan desa.

Penyelenggaraan pemerintahan desa memerlukan sumber daya manusia yang antisipatif dan inisiatif. Pemerintah desa harus antisipatif terhadap segala masalah, baik yang sudah eksis maupun secara potensial akan membebani desa. Masalah-masalah ini muncul sebagai akibat dari kekurangmampuan perangkat desa untuk melakukan identifikasi masalah-masalah yang dihadapi (Evi, 2015).

Menurut Gaffar (2016) Kepala Desa dalam menyelenggarakan pemerintahan berkewajiban melakukan koordinasi, integrasi dan sinkronisasi. Setiap pimpinan satuan organisasi pemerintah desa mengadakan pengawasan dan evaluasi pelaksanaan fungsi dan tugasnya. Setiap pimpinan satuan organisasi melaporkan hasil pelaksanaan fungsi dan tugasnya kepada atasannya secara tertulis, rutin dan/atau berkala (Hanif, 2015). Selain kewajiban tersebut, setiap pimpinan satuan organisasi pemerintah desa bertanggungjawab memimpin dan mengoordinasikan bawahannya serta memberikan bimbingan dan petunjukpetunjuk bagi pelaksanaan tugas masing-masing. Sekretaris Desa mengoordinasikan pelaksanaan teknis administrasi penyelenggaraan pemerintahan desa. Sekretaris Desa mewakili Kepala Desa apabila Kepala Desa sedang tidak ada di tempat atau berhalangan sementara.

Selain tugas, wewenang dan kewajibannya, kepala desa juga mendapatkan hak seperti yang diatur dalam Pasal 26 ayat 3 Undang-Undang Nomor 6 Tahun 2014 tentang Desa, bahwa: "Dalam melaksanakan tugas, Kepala Desa berhak mengusulkan struktur organisasi dan tata kerja Pemerintah Desa; mengajukan rancangan dan menetapkan Peraturan Desa; menerima penghasilan tetap setiap bulan, tunjangan, dan penerimaan lainnya yang sah, serta mendapat jaminan kesehatan; mendapatkan perlindungan hukum atas kebijakan yang dilaksanakan; dan memberikan mandat pelaksanaan tugas dan kewajiban lainnya kepada perangkat desa.

Kepala Desa dalam melaksanakan tugasnya berhak mendapatkan pelindungan hukum atas kebijakan yang dilaksanakan (Hermien, 2015). Akan tetapi, selama ini belum pernah ada aturan atau norma yang mengatur hal tersebut. Sehingga Kepala Desa dalam melaksanakan kebijakan sangat berhati-hati dan cenderung ketakutan akan dampak hukum yang berakibat lambatnya pembangunan sumber daya masyarakat desa dan infrastruktur desa.

Guna mendukung pelaksanaan tugas dan fungsi desa dalam penyelenggaraan pemerintahan dan pembangunan desa dalam segala aspeknya sesuai dengan kewenangan yang dimiliki, maka Undang-Undang Nomor 6 Tahun 2014 telah memberikan mandat kepada Pemerintah untuk mengalokasikan dana Desa. Dana Desa tersebut dianggarkan setiap tahun dalam APBN yang diberikan kepada setiap desa sebagai salah satu sumber pendapatan desa. Kebijakan ini sekaligus mengintegrasikan dan mengoptimalkan seluruh skema pengalokasian anggaran dari pemerintah kepada desa yang selama ini sudah ada.

Faktor yang menghambat pengelolaan Alokasi Dana Desa (ADD) yakni Rendahnya partisipasi masyarakat dalam mengibahkan tanahnya kepada Pemerintah Desa, Sarana dan Prasarana yang kurang memadai, Keterbatasan kualitas Sumber Daya Manusia Aparat pemerintah Desa di Desa Sabaru yang rata-rata berpendidikan SMA/SMK (Nur, at.al, 2019).

Menurut Ni'matul (2015) Struktur kewenangan yang dimiliki oleh desa berhubungan erat dengan struktur keuangan desa. Struktur keuangan desa merupakan hirarki struktur keuangan sentral dari struktur keuangan kabupaten atau kota, propinsi, dan pusat. Sumber pendapatan utama terbesar bagi desa masih merupakan alokasi kabupaten atau pusat dan hasil tanah kas desa. Kedua sumber pendapatan ini merupakan sumber pendapatan utama bagi desa dalam rangka otonomi desa.

Aspek penting dalam pelaksanaan dana desa adalah penyaluran dana desa dari APBN ke pemerintah desa. Meski dana desa merupakan hak pemerintah desa, namun dalam pelaksanaannya penyaluran dana desa tetap melibatkan peran dan fungsi Pemerintah kabupaten/kota sesuai dengan kewenangannya. Untuk mewujudkan prinsip transparansi dan akuntabilitas serta memastikan capaian penggunaan dana desa, proses penyaluran dana desa mempersyaratkan beberapa kriteria yang harus dipenuhi 
terlebih dahulu, baik oleh pemerintah desa sebagai pengguna dana desa maupun oleh kabupaten/kota.

Pemahaman mengenai pengelolaan dana desa di desa menjadi aspek penting dan mendasar yang harus dimiliki oleh para pemangku kepentingan di level pemerintah desa, khususnya perangkat desa, dalam mewujudkan transparansi dan akuntabilitas keuangan desa. Dalam pengelolaan keuangan desa khususnya di Kabupaten Wajo masih ditemui berbagai permasalahan, terutama penyelesaian pertanggungjawaban keuangan desa, seringkali desa terlambat dalam membuat pelaporam dan pertanggungjawaban penggunaan dana Alokasi Dana Desa. Padahal, batas maksimal pemerintah desa menyelesaikan pelaporan pertanggungjawaban penggunaan Alokasi Dana Desa yakni 3 (tiga) bulan setelah dana desa cair dan diterima, sehingga dalam pengelolaan dana desa tersebut perlu ada evaluasi guna mencegah terjadinya penyalahgunaan dana desa oleh Kepala Desa.

Evaluasi dalam pengelolaan dana desa diperlukan untuk memastikan di setiap tahapan pengelolaan dana desa tidak terjadi penyimpangan. Pelaksanaan evaluasi dilakukan secara berjenjang dari level pusat hingga daerah. Proses evaluasi di tingkat pusat dilakukan oleh Kementerian Keuangan, bersama dengan Kementerian Dalam Negeri dan Kementerian Desa. Secara umum, proses evaluasi dilakukan sejak dari tahapan perencanaan sampai dengan tahapan laporan pertanggungjawaban. Proses pelaksanaan evaluasi oleh pemerintah pusat dilakukan secara sinergis dan terpadu. Hal tersebut sangat diperlukan untuk memastikan bahwa penggunaan dana desa sesuai dengan prioritas yang ditetapkan dan untuk memastikan ketercapaian output dapat lebih maksimal. Agar proses evaluasi dapat lebih efektif, maka ditetapkan mekanisme pemberian sanksi yang apabila dalam implementasi pengelolaan dana desa terdapat penyimpangan atau penyalahgunaan dana desa yang dilakukan Kepala Desa termasuk di Wilayah Polres Wajo.

Upaya penegakan hukum yang dilakukan oleh pemerintah, tidak dapat dilepaskan dari Kepolisian. Tugas pokok Polri menurut Undang-Undang Nomor 2 Tahun 2002 tentang Kepolisian adalah memelihara keamanan dan ketertiban masyarakat, menegakkan hukum, dan memberikan perlindungan, pengayoman, dan pelayanan kepada masyarakat. Tugas penegakan hukum berkaitan dengan Sistem Peradilan Pidana di mana Polri menjadi salah satu bagian penegakan hukum selain Hakim dan jaksa. Dalam Sistem Peradilan Pidana tersebut, Polri diberi wewenang untuk melakukan upaya paksa yang meliputi: kegiatan penangkapan, penahanan, penggeledahan dan penyitaan.

Dalam sistem peradilan pidana maka proses penyidikan merupakan tahapan awal dalam upaya pemberantasan tindak pidana korupsi. Dengan demikian, keberhasilan pada tahap penyidikan akan sangat menentukan tahapan berikutnya. Dalam menangani tindak pidana korupsi yang dilakukan oleh Kepala Desa, polisi memegang peran yang sangat penting karena polisi merupakan pintu masuk seseorang ke dalam sistem peradilan pidana. Di sisi lain peran Jaksa juga sangat penting oleh karena apa yang telah diperoleh Polisi dalam usaha penyidikan selaku penyidik, akan ditentukan oleh Jaksa apakah akan diteruskan ke pengadilan atau tidak.
Hakim pengadilan yang memberi putusan dan terakhir adalah lembaga pemasyarakatan yang mengelola terdakwa agar tidak kembali melakukan tindak pidana korupsi. Oleh karena itu, masalah penegakan hukum seperti penyidikan, penuntutan peradilan, pelaksanaan hukuman, harus berada dalam suatu koordinasi yang baik.

Tujuan penelitian ini adalah untuk mengetahui dan menganalisis penegakan hukum terhadap penyalahgunaan dana desa oleh kepala desa di wilayah Polres Wajo dan untuk mengetahui dan menganalisis faktor-faktor yang mempengaruhi efektivitas penegakan hukum terhadap penyalahgunaan dana desa oleh kepala desa di wilayah Polres Wajo.

\section{METODE}

Tipe penelitian ini adalah penelitian deskriptif dengan pendekatan yuridis-empiris atau pendekatan tipe normatif dan empiris. Sedangkan sifat dari penelitian ini adalah deskriptif dan preskriptif (apa yang seharusnya). Penelitian ini dilaksanakan di Kabupaten Wajo yaitu tepatnya di Polres Wajo.

Populasi dalam penelitian ini, antara lain: seluruh warga desa di Wilayah Polres Wajo. Sampel dalam penelitian ini ditentukan sebanyak 50 orang responden dengan menggunakan teknik purposive sampling atau secara sengaja karena dapat memberikan keterangan dan informasi yang jelas tentang penegakan hukum terhadap penyalahgunaan dana desa oleh kepala desa di Wilayah Polres Wajo. Jenis data yang diperlukan dalam penelitian ini adalah data primer dan data sekunder. Metode pengumpulan data yang digunakan adalah melalui wawancara, dokumentasi dan kuesioner (angket).

Analisis data menggunakan metode analisis kualitatif dan kuantitatif, sebagai berikut:

1. Analisis data kualitatif dilakukan terhadap data yang tidak dapat dikuantifikasikan, seperti: bahan pustaka, hasil wawancara, dan peraturan perundang-undangan yang berhubungan dengan masalah yang dikaji.

2. Analisis data kuantitatif dilakukan terhadap data yang dikuantifikasikan dan akan dianalisis melalui tabel distribusi frekuensi untuk dijadikan bahan pengambilan kesimpulan dengan rumus (Soejono Soekanto, 2011) sebagai berikut:

$$
P=\frac{f}{n} x 100 \%
$$

Keterangan:

$$
\begin{array}{ll}
P & =\text { Persentase } \\
f & =\text { Frekuensi (nilai yang diperoleh) } \\
n & =\text { Jumlah responden (jumlah seluruh nilai) } \\
100 \% & =\text { Angka pembulat. }
\end{array}
$$

\section{HASIL DAN PEMBAHASAN}

\subsection{Penegakan Hukum Terhadap Penyalahgunaan Dana Desa di Wilayah polres Wajo}

Sebagaimana Desa merupakan representasi dari kesatuan masyarakat hukum terkecil yang telah ada dan tumbuh berkembang seiring sejarah kehidupan masyarakat Indonesia dan menjadi bagian yang tidak terpisahkan dari tatanan kehidupan bangsa Indonesia. Sebagai wujud pengakuan Negara terhadap Desa, khususnya dalam memperjelas fungsi dan kewenangan desa, serta memperkuat kedudukan desa dan masyarakat desa sebagai subyek pembangunan, diperlukan 
kebijakan penataan dan pengaturan mengenai desa yang diwujudkan dengan lahirnya UU Nomor 6 Tahun 2014 tentang Desa.

Pemerintahan desa adalah penyelenggaraan urusan pemerintahan dan kepentingan masyarakat setempat dalam sistem pemerintahan Negera Kesatuan Republik Indonesia, sebagaimana dimaksud Undang-undang No. 6 Tahun 2014 tentang Desa. Untuk mejalankan urusan pemrintahannya, kepala desa telah diberikan beberapa asas yang harus dipergunakan sebagai landasan cara kerja efektif dan mampu dipertanggungjawabkan kepada masyarakat dalam menjalankan kewenangannya. Asas-asas tersebut akan membawa dampak positif apabila dapat dilaksanakan dengan penuh kesadaran oleh kepala desa dan perangkat desa.

Pemerintah desa diselengarakan di bawah pimpinan seorang kepala desa beserta para pembantunya (Perangkat Desa), mewakili masyarakat desa guna hubungan ke luar maupun ke dalam masyarakat bersangkutan. Fungsi pemerintah desa merupakan gejala sosial, karena harus diwujudkan dalam interaksi antar individu di dalam situasi sosial suatu kelompok masyarakat. Fungsi secara operasional dapat dibedakan dalam fungsi pokok, yaitu sebagai berikut:

a. Fungsi Instruktif, Fungsi ini bersifat komunikasi satu arah. Pemerintah sebagai komunikator merupakan pihak yang menentukan apa, bagaimana, bilamana, dan dimana pemerintah itu dikerjakan agar keputusan dapat dilaksanakan secara efektif.

b. Fungsi Konsultatif, Fungsi ini digunakan sebagai komunikasi dua arah. Hal tersebut digunakan sebagai usaha untuk menetapkan keputusan yang memerlukan bahan pertimbangan dan mungkin perlu konsultasi dengan masayarakat-masyarakat yang dipimpinnya.

c. Fungsi Partisipasi, Dalam menjalankan fungsi ini pemerintah desa berusaha mengaktifkan masyarakatnya, baik dalam keikutsertaan mengambil keputusan maupun dalam melaksanakannya. Partisipasi tidak berarti bebas berbuat semaunya, tetapi dilakukan secara terkendali dan terarah berupa kerjasama dengan tidak mencampuri atau mengambil tugas pokok orang lain.

d. Fungsi Delegasi, Fungsi ini dilaksanakan dengan memberikan pelimpahan wewenang membuat atau menetapkan baik melalui persetujuan maupun tanpa persetujuan pemerintah. Fungsi delegasi ini pada dasarnya berarti kepercayaan.

e. Fungsi Pengendalian, Fungsi pengendalian berasumsi bahwa kepemimpinan yang efektif harus mampu mengantar aktivitas anggotanya secara terarah. Koordinasi yang efektif, sehingga memungkinkan tercapainya tujuan bersama secara maksimal dalam melaksanakan fungsi pengendalian pemimpin dapat mewujudkannya melalui kegiatan bimbingan, pengarahan, koordinasi dan pengawasan.

Undang-Undang Nomor 6 Tahun 2014 tentang Desa memuat kebijakan dalam memberi pelayanan, peningkatan peranserta dan pemberdayaan masyarakat desa yang ditujukan bagi kesejahteraan masyarakat. Hal ini memberikan keleluasaan kepada desa agar lebih mandiri dan kreatif dalam meningkatkan kesejahteraan masyarakat desa melalui pengelolaan keuangan desa.

Keuangan desa dikelola berdasarkan azas-azas transparan, akuntabel, partisipatif serta dilakukan dengan tertib dan disiplin anggaran. Dalam penyusunan Rancangan anggaran Pembelanjaan Desa, Kepala desa harusnya selalu berkoordinasi dengan perangkat desa dan Lembaga yang ada di desa untuk meyusun Rancangan anggaran Pembelanjaan Desa yang nantinya kegunaannya untuk pembangunan desa dan pemberdayaan masyarakat desa.

Asas-asas pemerintahan dipergunakan sebagai pedoman dalam berprilaku dalam penyelenggaraan pemerintahan. apabila aparatur desa menjalankannya dengan maksimal akan dapat memberikan gambaran bahwa kinerjanya akan menghasilkan capaian yang diharapkan oleh undang-undang dan masyarkat.

Berdasarkan aturan dalam perundang-undangan, maka dalam pengelolaan dana desa diperlukan mekanisme kontrol dari masyarakat agar dapat dipergunakan tepat sasaran yaitu untuk meningkatkan kesejahteraan rakyat. Pemerintah desa dalam hal pengelolaan dana desa ini dituntut untuk akuntabel dan transparan agar dana tidak diselewengkan. Badan Permusyawaratan Desa harus bisa menjalankan perannya secara sungguh-sungguh khususnya dalam pengelolaan dana desa. Badan Permusyawaratan Desa tidak perlu ragu dalam menjalankan fungsi pengawasan karena sudah ada UndangUndang dan Peraturan Pemerintah yang menjadi payung hukum yang jelas. Harus ada check and balance dalam hal ini agar dapat meminimalisir penyalahgunaan dana desa. Kesesuian Badan Permusyawaratan Desa dalam pengelolaan dana desa sangat penting karena akan mempengaruhi terlaksanannya pemerintahan daerah khususnya desa. Peran Badan Permusyawaratan Desa harus sesuai dengan peraturan yang berlaku agar penyalahgunaan dana desa oleh Kepala Desa dapat diminimalisir.

Penegakan hukum terhadap penyalahgunaan dana desa tentu tidak terlepas dari peran Pejabat Polri sebagai penyidik. Untuk mendukung tugas Kepolisian sebagai penyidik, maka diatur pula di dalam KUHAP kewajiban dan wewenang Pejabat Polisi dalam kegiatan penyidikan. Hal ini dijabarkan lebih lanjut dalam Undang-Undang No. 2 Tahun 2002 Tentang Kepolisian Negara dan Peraturan Kepala Kepolisian Negara Republik Indonesia Nomor 14 Tahun 2012 tentang Manajemen Penyidikan Tindak Pidana. Dalam Pasal 4 Peraturan Kepala Kepolisian Negara Republik Indonesia Nomor 14 Tahun 2012, disebutkan bahwa dasar dilakukannya penyidikan, antara lain: laporan polisi/pengaduan, surat perintah tugas, laporan hasil penyelidikan (LHP), surat perintah penyidikan, dan SPDP.

Sehubungan dengan proses penyidikan penyalahgunaan dana desa di wilayah Polres Wajo, dimana penyidik tidak secara serta-merta dapat melakukan kegiatan penyidikan dengan semaunya, melainkan ada batasan-batasan yang harus diikuti oleh penyidik agar tidak melanggar hak asasi manusia mengingat kekuasaan penyidik dalam melakukan rangkaian tindakan tersebut terlampau besar.

Batasan-batasan kegiatan penyidik terdapat pada Peraturan Kepala Kepolisian Negara Republik Indonesia Nomor 8 Tahun 2009 Tentang Implementasi Prinsip dan Standar Hak Asasi Manusia dalam Penyelenggaraan Tugas Kepolisan Republik Indonesia. Di dalam Pasal 13 ayat (1) Peraturan tersebut disebutkan bahwa dalam melaksanakan kegiatan penyidik, dilarang: (1) Melakukan intimidasi, ancaman, siksaan fisik, psikis ataupun seksual untuk mendapatkan informasi, keterangan atau pengakuan; (2) Menyuruh atau menghasut orang lain untuk melakukan tindakan kekerasan di luar proses hukum; (3) Memberitakan rahasia seseorang yang berperkara; (4) Memanipulasi atau berbohong dalam membuat atau menyampaikan laporan hasil penyelidikan; (5) Merekayasa laporan sehingga mengaburkan investigasi/memutarbalikkan kebenaran; dan (6) Melakukan 
tindakan yang bertujuan untuk meminta imbalan dari pihak yang berperkara.

Menurut Kepala Desa di Wilayah Polres Wajo (wawancara, tanggal 8 Maret 2019) bahwa:

"Kebanyakan sosok Kepala Desa bukanlah orang yang mengerti tentang hukum, baik hukum administrasi maupun hukum yang lain. Keterbatasan sumber daya manusialah yang memungkinkan Kepala Desa melakukan perbuatan melanggar hukum, yang awalnya bisa saja menurutnya mempunyai kemanfaatan, tapi di sisi lain yang dilakukan telah menyalahi peraturan perundang-undangan".

Informasi di atas menunjukkan bahwa perlu adanya perlindungan hukum bagi kepala desa dalam melaksanakan kebijakan desa, sangatlah penting seperti yang telah diamanatkan di dalam poin d Pasal 26 ayat 3 Undang-Undang Nomor 6 Tahun 2014 tentang Desa. Akan tetapi dalam pasal tersebut hanya menyatakan "mendapatkan perlindungan hukum atas kebijakan yang dilaksanakan".

Menurut Kepala Desa di Wilayah Polres Wajo (wawancara, tanggal 8 Maret 2019) bahwa:

"Kepala desa tidak mengetahui bentuk perlindungan hukum apa yang diberikan kepadanya. Dan sampai saat ini implikasi terhadap perlindungan hukum tersebut banyak yang tidak berjalan dengan baik, sehingga berpengaruh terhadap pembangunan desa dan pemberdayaan masyarakat desa dikarenakan adanya kekhawatiran kepala desa akan sanksi pidana apabila salah dalam melaksanakan kebijakan".

Berdasarkan hasil dari penelitian, maka dapat dijelaskan bahwa penegakan hukum terhadap penyalahgunaan dana desa oleh kepala desa di Wilayah Polres Wajo sudah dilaksanakan sesuai peraturan perundang-undangan yang berlaku, dimana keempat unsur Tindak Pidana Korupsi pada Pasal 2 ayat (1) subs Pasal 3 lebih subs Pasal 9 UU No. 31 tahun 1999 sebagaimana telah diubah dalam UU No. 20 tahun 2001 tentang pemberantasan Tindak Pidana Korupsi terpenuhi keseluruhan rangkaian perbuatan yang dilakukan oleh Tersangka Sdr. AF adalah sebuah Tindak Pidana Korupsi berdasarkan Pasal 2 ayat (1) Subs Pasal 3 lebih Subs Pasal 9 Undang-Undang RI No. 31 tahun 1999 sebagaimana telah diubah dalam Undang-Undang RI No. 20 tahun 2001 tentang Pemberantasan Tindak Pidana Korupsi, Jo. Pasal 55 ayat (1) ke-1e KUHPidana sehingga Tersangka Sdr. AF dapat dituntut untuk di pidana penjara.

Selanjutnya efektivitas penegakan hukum terhadap penyalahgunaan dana desa di Wilayah Polres Wajo juga dapat diketahui melalui tanggapan dari 50 orang responden seperti yang tertera pada tabel berikut ini.

Tabel 1.

Jawaban Responden Tentang Efektivitas Penegakan Hukum Terhadap Penyalahgunaan Dana Desa di Wilayah Polres Wajo

\begin{tabular}{clcc}
\hline No. & Kategori Jawaban & Frekuensi & Persentase \\
\hline 1. & Efektif & 25 & 50 \\
2. & Cukup efektif & 19 & 38 \\
3. & Tidak efektif & 6 & 12 \\
\hline & Jumlah & 50 & 100 \\
\hline
\end{tabular}

Sumber: Data Primer Tahun 2019

Berdasarkan data pada tabel di atas dapat dijelaskan bahwa efektivitas penegakan hukum terhadap penyalahgunaan dana desa di Wilayah Polres Wajo, ditanggapi bervariatif oleh responden, di mana diperoleh jawaban yang menyatakan efektif sebanyak 25 orang atau sebesar $50 \%$, menyatakan kurang efektif sebanyak 19 orang responden atau sebesar
$38 \%$, dan menyatakan tidak efektif sebanyak 6 orang responden atau sebesar $12 \%$. Dari data tersebut menunjukkan bahwa pada umumnya responden menyatakan efektif, sehingga dapat dikatakan bahwa penegakan hukum terhadap penyalahgunaan dana desa di Wilayah Polres Wajo terlaksana efektif sesuai peraturan perundang-undangan yang berlaku. Meskipun demikian, penegakan hukum perlu terus diberdayakan secara maksimal agar dapat diwujudkan efektivitas penegakan hukum terhadap penyalahgunaan dana desa di Wilayah Polres Wajo di masa akan datang.

\subsection{Faktor-Faktor yang Mempengaruhi Efektifitas Penyalahgunaan Dana Desa di Wilayah Polres Wajo}

Kejahatan timbul karena niat dan kesempatan dari pelakunya. Begitu pula halnya dengan korupsi yang terjadi di desa. Ada beberapa hal yang memotivasi kepala desa untuk melakukan korupsi, yaitu:

a. Kepala desa sering terkondisikan ujung tombak dan lebih ujung tombak. Seorang kepala desa harus siap 24 jam untuk melayani masyarakat. Mulai bayi lahir sampai warganya yang meninggal, maka kepala desa harus datang. Ada yang kurang apabila kepala desa tidak hadir dalam setiap acara warganya. Profesi kepala desa, tidak mengenal hari libur. Selain itu, setiap acara warganya maka kepala desa harus memberikan sumbangan. Sumbangan bukan satu hari satu tetapi bisa lebih dari itu. Padahal kondisi gaji kepala desa kecil di mana hanya mengandalkan sumbangan berupa hasil bumi: padi, kelapa, atau tanah bengkok gersang.

b. Kepala desa terpilih berdasarkan sisi elektabilitas bagus, namun sisi modalitas ekonomi sangat lemah sehingga terdorong untuk melakukan tindak pidana korupsi. Dengan demikian, ada kecenderungan untuk mengembalikan finansial politiknya.

c. Posisi kepala desa menjadi pundi-pundi partai politik di akar rumput. Bukan rahasia umum apabila era sekarang sampai tingkat desa pun partai politik menancapkan akar politiknya dengan menempatkan kadernya sebagai kepala desa. Pentingnya politik di tingkat lokal karena: (1) Politik lokal merupakan laboratorium pembelajaran dalam kerangka yang lebih umum dan sensitif; (2) Politik lokal merupakan arena pertama berlangsungnya untuk berpartisipasi politik; (3) Politik lokal merupakan barometer kehidupan sehari-hari sehingga bisa dijadikan pertimbangan oleh pemerintah dan stakeholders. Argumentasi di awal bukan merupakan pembenaran, afirmasi terhadap korupsi tetapi harus menjadi musuh bersama. Korupsi merupakan kejahatan luar biasa (extraordinary crime).

d. Kurangnya pengawasan dan keterbukaan dalam penyelenggaraan pemerintahan desa. Hal ini karena masyarakat desa biasanya lebih fokus melakukan aktivitas keseharian seperti bertani, berdagang, dan melaut. Urusan pemerintahan, penganggaran dianggap merupakan pekerjaan orang-orang pintar, tokoh desa saja. Badan Permusyawaratan Desa (BPD), organisasi kepemudaan tidak berfungsi karena mayoritas lebih banyak migrasi ke kota besar.

Setiap struktur formal terdapat kecenderungan bertambahnya personil dalam satuan-satuan organisasi. Setiap kali mendapat tugas, biasanya para pejabat akan membentuk satuan-satuan atau gugus birokrasi baru atau merekrut orangorang baru. Ini mengakibatkan membengkaknya birokrasi 
baik dari segi jumlah satuan maupun jumlah pegawainya. Karena lahan dan sumber penghasilan yang bisa digali oleh pergawai itu menjadi lebih terbatas, sehingga akhirnya terdorong untuk melakukan korupsi. Pada dasarnya ini bukanlah satu-satunya faktor yang mendorong pegawai melakukan korupsi. Faktor-faktor yang memotivasi untuk korupsi sangat beragam dan seringkali antara satu faktor menguatkan faktor lain. Selain itu, modus korupsi bisa terungkap dari struktur birokrasi pemerintahan patrimonial di tingkat desa. Dengan melekatnya budaya birokrasi patrimonial maka tidak bisa dibedakan ruang publik dan privat, ruang pribadi dan ruang resmi atau kedinasan.

Menurut Wertheim bahwa berbagai bentuk korupsi dalam kaitan sejarah, sikap hidup, dan struktur sosial masyarakat setempat. Dengan demikian tidak terjadi checks and balances di tingkat desa. Namun modus-modus korupsi harus diketahui dahulu meskipun di tingkat desa sekalipun. Adapun modus-modus terjadinya korupsi di tingkat desa antara lain:

1. Pengurangan alokasi Alokasi Dana Desa (ADD), misalnya, dana ADD dijadikan "kue" pegawai desa untuk kepentingan pribadi.

2. Pemotongan alokasi Bantuan Langsung Tunai (BLT), misalnya, pemotongan tersebut karena azas pemerataan, keadilan untuk didistribusikan keluarga miskin yang tidak terdaftar. Namun yang jamak terjadi bahwa pemotongan BLT banyak disalahgunakan pengurusnya di tingkat desa.

3. Pengurangan jatah beras untuk rakyat miskin (raskin), misalnya, pemotongan 1-2 kg per Kepala Keluarga (KK). Apabila dikalkulasikan maka akan menghasilkan jumlah yang besar yang kemudian hasilnya dimanfaatkan untuk memperkaya diri sendiri.

4. Penjualan Tanah Kas Desa (Bengkok).

5. Penyewaan Tanah Kas Desa (TKD) yang bukan haknya, misalnya, TKD untuk perumahan.

6. Pungutan liar suatu program padahal program tersebut seharusnya gratis, misalnya sertifikasi (pemutihan) tanah, Kartu Keluarga (KK), Kartu Tanda Penduduk (KTP).

7. Memalsukan proposal bantuan sosial, misalnya menyelewengkan bantuan sapi.

Sehubungan dengan efektifitas penegakan hukum terhadap penyalahgunaan dana desa oleh kepala desa di wilayah Polres Wajo ditentukan oleh beberapa faktor, antara lain: substansi hukum, struktur hukum, sarana dan prasarana hukum, budaya hukum, dan kesadaran hukum. Adapun pengaruh substansi hukum, struktur hukum, sarana dan prasarana hukum, budaya hukum, kesadaran hukum, dan biaya operasional terhadap penyalahgunaan dana desa oleh kepala desa di wilayah Polres Wajo, akan diuraikan berikut ini.

1. Substansi Hukum

Substansi adalah keseluruhan asas hukum, norma hukum dan aturan hukum, baik yang tertulis maupun yang tidak tertulis, termasuk sumber daya peraturan perundangundangan. Peraturan perundang-undangan dalam hal ini adalah wujud dari ketentuan dalam undang-undang yang berkaitan dengan tindak pidana korupsi. Apabila ketentuan dalam undang-undang tindak pidana korupsi kurang sempurna atau tidak lengkap, maka hal itu tentu berpengaruh terhadap penegakan hukum dalam penanggulangan penyalahgunaan dana desa oleh kepala desa di wilayah Polres Wajo.
Peran Polri sebagai penyidik utama di dalam perkaraperkara pidana, maka kewenangan Polri dalam kegiatan penyidikan perkara pidana diatur dalam KUHAP Pasal 7 ayat (1) dan dijabarkan lebih lanjut dalam Undang-Undang No. 2 Tahun 2002 Tentang Kepolisian Negara. Penegakan hukum yang terkait dengan penyalahgunaan dana desa oleh kepala desa di wilayah Polres Wajo telah dilakukan dengan berdasarkan UU Nomor 31 Tahun 1999 tentang Pemberantasan Tindak Pidana Korupsi juncto UU No. 20 Tahun 2001 tentang Perubahan atas UU Nomor 31 Tahun 1999 Tentang Pemberantasan Tindak Pidana Korupsi. Dalam ketentuan undang-undang disebutkan tindak pidana korupsi merupakan tindak pidana yang luar biasa (extra ordinary crime) sehingga diperlukan tindakan yang luar biasa pula (extra ordinary measures). Oleh karena itu, pemberantasan tindak pidana korupsi perlu segera dilakukan secara tuntas dan berkesinambungan agar tidak memberikan kerugian yang besar bagi Negara.

Adapun jawaban responden tentang pengaruh substansi hukum terhadap efektivitas penegakan hukum penyalahgunaan dana desa oleh kepala desa di wilayah Polres Wajo, dapat diketahui melalui jawaban dari 50 orang responden seperti yang terlihat pada tabel berikut ini.

$$
\text { Tabel } 2 .
$$

Jawaban Responden Tentang Pengaruh Substansi Hukum Terhadap Efektivitas Penegakan Hukum Penyalahgunaan Dana Desa Oleh Kepala Desa di wilayah Polres Wajo

\begin{tabular}{clcc}
\hline No. & Kategori Jawaban & Frekuensi & Persentase \\
\hline 1. & Berpengaruh & 30 & 60 \\
2. & Kurang berpengaruh & 15 & 30 \\
3. & Tidak berpengaruh & 5 & 10 \\
\hline & Jumlah & 50 & 100 \\
\hline
\end{tabular}

Sumber: Data Primer tahun 2019

Berdasarkan data pada tabel di atas menunjukkan bahwa pengaruh substansi hukum terhadap efektivitas penegakan hukum penyalahgunaan dana desa oleh kepala desa di wilayah Polres Wajo, yang menyatakan berpengaruh sebanyak 30 orang responden $(60 \%)$, yang menyatakan kurang berpengaruh sebanyak 15 orang responden (30\%), dan menyatakan tidak berpengaruh sebanyak 5 orang responden (10\%). Hal ini berarti substansi hukum berpengaruh terhadap efektivitas penegakan hukum penyalahgunaan dana desa oleh kepala desa di wilayah Polres Wajo.

2. Struktur Hukum

Struktur hukum adalah keseluruhan institusi penegakan hukum, beserta aparatnya, termasuk: kepolisian dengan para polisinya. Kunci penegakan hukum yang adil dan berwibawa adalah mentalitas atau kepribadian penegak hukum di Polres Wajo. Hal ini berarti ada kecenderungan yang kuat di kalangan masyarakat untuk mengartikan hukum sebagai petugas atau penegak hukum. Artinya, hukum diidentikkan dengan tingkah laku nyata petugas atau penegak hukum termasuk penyidik kepolisian. Apabila sikap tindak petugas atau penegak hukum dianggap adil, maka dengan sendirinya juga akan berkembang suatu persepsi bahwa hukumnya sudah cukup baik

Efektivitas penegakan hukum terhadap penyalahgunaan dana desa oleh kepala desa di wilayah Polres Wajo Semua pihak dapat terlibat dalam mekanisme pengawasan, yaitu Masyarakat Desa, Camat, Badan Permusyawaratan Desa (BPD), Aparat Pengawas Intern Pemerintah (APIP), dan Badan Pemeriksa Keuangan (BPK). Bahkan dapat diikuti dalam perkembangan terakhir Komisi Pemberantasan Korupsi 
(KPK) juga telah melakukan pengawasan pengelolaan dana desa. Untuk tingkat pusat, pengawasan telah dilakukan sinergi dengan semua pihak. Agar mekanisme pengawasan semakin efektif maka dimungkinkan diberikan sanksi kepada pihak yang tidak melaksanakan ketentuan sebagaimana yang telah ditetapkan. Dengan adanya sanksi tersebut maka diharapkan dapat meminimalisasi terjadinya pelanggaran dalam pengelolaan dana desa oleh Kepala Desa.

Adapun jawaban responden tentang pengaruh struktur hukum terhadap efektivitas penegakan hukum penyalahgunaan dana desa oleh kepala desa di wilayah Polres Wajo, dapat dilihat pada tabel berikut ini.

\section{Tabel 3.}

Jawaban Responden Tentang Pengaruh Struktur Hukum Terhadap Efektivitas Penegakan Hukum Penyalahgunaan Dana Desa Oleh Kepala Desa di wilayah Polres Wajo

\begin{tabular}{clcc}
\hline No. & Kategori Jawaban & Frekuensi & Persentase \\
\hline 1. & Berpengaruh & 26 & 52 \\
2. & Kurang berpengaruh & 20 & 40 \\
3. & Tidak berpengaruh & 4 & 8 \\
\hline & Jumlah & 50 & 100
\end{tabular}

Sumber: Data Primer Tahun 2019

Berdasarkan data pada tabel di atas menunjukkan pengaruh struktur hukum terhadap efektivitas penegakan hukum penyalahgunaan dana desa oleh kepala desa di wilayah Polres Wajo, yang menyatakan berpengaruh sebanyak 26 orang responden $(52 \%)$, yang menyatakan kurang berpengaruh sebanyak 20 orang $(40 \%)$, dan yang menyatakan tidak berpengaruh sebanyak 4 orang responden (8\%). Hal ini berarti struktur hukum berpengaruh terhadap efektivitas penegakan hukum penyalahgunaan dana desa oleh kepala desa di wilayah Polres Wajo.

\section{Sarana dan Prasarana}

Faktor sarana dan prasarana juga mempengaruhi efektivitas penegakan hukum penyalahgunaan dana desa oleh kepala desa di wilayah Polres Wajo. Ketersediaan sarana dan prasarana yang memadai diharapkan dapat memperlancar mekanisme dari proses kerja Polri dalam penyidikan dengan efektif. Pelaksanaan penyidikan yang tidak disertai sarana dan prasarana yang memadai tentu tidak akan terlaksana secara efektif. Pelaksanaan penyidikan oleh Polri harus diikuti pula oleh pemberian sumber-sumber daya yang dibutuhkan untuk mendukung pelaksanaan tugas Polri tersebut. Sarana dan prasarana seperti fasilitas kantor termasuk kendaraan, perlengkapan kantor, komputer dan lain-lain serta gedung juga menunjang aktivitas penegakan hukum terhadap penyalahgunaan dana desa oleh Kepada Desa.

Adapun jawaban responden tentang pengaruh sarana dan prasarana terhadap efektivitas penegakan hukum penyalahgunaan dana desa oleh kepala desa di wilayah Polres Wajo, dapat dilihat pada tabel berikut ini.

Tabel 4.

Jawaban Responden Tentang Pengaruh Sarana Dan Prasarana

Terhadap Efektivitas Penegakan Hukum Penyalahgunaan

Dana Desa Oleh Kepala Desa Di Wilayah Polres Wajo

\begin{tabular}{clcc}
\hline No. & Jawaban Responden & Frekuensi & Persentase \\
\hline 1. & Berpengaruh & 32 & 64 \\
2. & Kurang berpengaruh & 14 & 28 \\
3. & Tidak berpengaruh & 4 & 8 \\
\hline & Jumlah & 50 & 100 \\
\hline
\end{tabular}

Sumber: Data primer diolah tahun 2019
Tabel di atas menunjukkan bahwa jawaban responden tentang pengaruh sarana dan prasarana terhadap efektivitas penegakan hukum penyalahgunaan dana desa oleh kepala desa di wilayah Polres Wajo, yaitu: 32 orang responden (64\%) menyatakan berpengaruh, dan 14 orang responden $(28 \%)$ menyatakan kurang berpengaruh, sedangkan yang menyatakan tidak berpengaruh terdapat 4 orang responden (8\%). Kecenderungan dari data tersebut menunjukkan bahwa sarana dan prasarana berpengaruh terhadap efektivitas penegakan hukum penyalahgunaan dana desa oleh kepala desa di wilayah Polres Wajo. Ketersediaan sarana dan prasarana yang memadai sangat diperlukan termasuk pengadaan ruang kerja lebih luas dan nyaman agar penegakan hukum penyalahgunaan dana desa oleh kepala desa di wilayah Polres Wajo dapat lebih diefektifkan di masa yang akan datang.

4. Budaya Hukum

Faktor budaya dapat mempengaruhi sikap, cara berfikir dan cara bertindak yang mengarah pada perbuatan negatif atau positif. Faktor budaya seperti tabiat kurang baik dan cara berpakaian yang mewah, ucapan atau omongan besar yang mewarnai ciri khas bukan hanya penduduk biasa tetapi juga sering dijumpai pada kelompok pejabat atau aparat penegak hukum dan tidak mengenal pangkat/jabatan yang tinggi atau rendah. Pemberian keteladanan yang baik dari pejabat/atasan dalam pelaksanaan tugas, fungsi dan kewenangan yang sesuai dengan peraturan perundang-undangan yang berlaku, namun tetap bijaksana sepanjang masih memiliki batas toleransi. Oleh karena itu, budaya hukum sangat menentukan efektifitas penegakan hukum penyalahgunaan dana desa oleh kepala desa di wilayah Polres Wajo.

Adapun pengaruh budaya hukum terhadap efektifitas penegakan hukum penyalahgunaan dana desa oleh kepala desa di wilayah Polres Wajo, dapat dilihat pada tabel berikut ini.

Tabel 5 .

Jawaban Responden Tentang Pengaruh Budaya Hukum

Terhadap Penegakan Hukum Penyalahgunaan Dana Desa Oleh Kepala Desa Di Wilayah Polres Wajo

\begin{tabular}{clcc}
\hline No. & Jawaban Responden & Frekuensi & Persentase \\
\hline 1. & Berpengaruh & 31 & 62 \\
2. & Kurang berpengaruh & 14 & 28 \\
3. & Tidak berpengaruh & 5 & 10 \\
\hline & Jumlah & 50 & 100 \\
\hline
\end{tabular}

Sumber: Data primer diolah tahun 2019

Tabel di atas menunjukkan bahwa jawaban responden tentang pengaruh budaya hukum terhadap efektivitas penegakan hukum penyalahgunaan dana desa oleh kepala desa di wilayah Polres Wajo, yaitu: 31 orang responden $(62 \%)$ menyatakan berpengaruh, dan 14 orang responden $(28 \%)$ menyatakan kurang berpengaruh, sedangkan yang menyatakan tidak berpengaruh terdapat 5 orang responden $(10 \%)$. Kecenderungan dari data menunjukkan bahwa faktor budaya hukum berpengaruh terhadap efektivitas penegakan hukum penyalahgunaan dana desa oleh kepala desa di wilayah Polres Wajo.

6. Kesadaran Hukum

Kesadaran hukum merupakan salah satu faktor yang mempengaruhi efektifitas penegakan hukum tindak pidana korupsi di Kota Makassar. Kesadaran hukum setiap orang dalam era pembangunan nasional sekarang ini, sangat dituntut keberadaannya. Apabila setiap orang telah memahami hak dan 
kewajibannya sebagai subyek hukum, maka kesadaran hukum masyarakat akan semakin meningkat. Kesadaran itu akan muncul karena adanya pemahaman dan pengetahuan hukum oleh masyarakat. Pengetahuan hukum akan meningkatkan kesadaran hukum bagi penegak hukum dan juga masyarakat, sehingga ketika melakukan tindakan yang melanggar peraturan perundang-undangan agar dapat segera memahami akibat hukum dari setiap tindakannya yang melawan hokum.

Adapun jawaban responden tentang pengaruh kesadaran hukum terhadap efektifitas penegakan hukum penyalahgunaan dana desa oleh kepala desa di wilayah Polres Wajo, dapat dilihat pada tabel berikut ini.

\section{Tabel 6.}

Jawaban Responden Tentang Pengaruh Kesadaran Hukum Terhadap Efektivitas Penegakan Hukum Penyalahgunaan Dana Desa Oleh Kepala Desa Di Wilayah Polres Wajo

\begin{tabular}{clcc}
\hline No. & Jawaban Responden & Frekuensi & Persentase \\
\hline 1. & Berpengaruh & 33 & 66 \\
2. & Kurang berpengaruh & 13 & 26 \\
3. & Tidak berpengaruh & 4 & 8 \\
\hline & Jumlah & 50 & 100 \\
\hline
\end{tabular}

Sumber: Data primer diolah tahun 2019

Tabel di atas menunjukkan bahwa jawaban responden tentang pengaruh kesadaran hukum terhadap efektivitas penegakan hukum penyalahgunaan dana desa oleh kepala desa di wilayah Polres Wajo, yaitu: 33 orang responden $(66 \%)$ menyatakan berpengaruh, dan 13 orang responden $(26 \%)$ menyatakan kurang berpengaruh, sedangkan yang menyatakan tidak berpengaruh terdapat 4 orang responden $(8 \%)$. Kecenderungan dari data tersebut menunjukkan bahwa kesadaran hukum berpengaruh terhadap efektivitas penegakan hukum penyalahgunaan dana desa oleh kepala desa di wilayah Polres Wajo.

7. Biaya operasional

Faktor biaya merupakan salah satu faktor yang menghambat dalam proses penegakan hukum yang terkait dengan pelaksanaan proses penyidikan oleh penyidik kepolisian dalam menangani perkara tindak pidana penyalahgunaan dana desa oleh Kepala Desa di wilayah Polres Wajo. Minimnya anggaran membuat tidak maksimal atau tidak efektifnya pelaksanaan proses penyidikan. Anggaran yang selama ini dalam pelaksanaan proses penyidikan oleh penyidik kepolisian dalam menangani perkara tindak pidana di Polres Wajo belum mencukupi sehingga dalam menuntaskan penegakan hukum masih terkendala dan tidak memuaskanAdapun pengaruh biaya operasional terhadap efektivitas penegakan hukum penyalahgunaan dana desa oleh kepala desa di wilayah Polres Wajo, dapat dilihat pada tabel berikut ini.

Tabel 7.

Jawaban Responden Tentang Pengaruh Biaya Operasional

Terhadap Efektivitas Penegakan Hukum Penyalahgunaan

Dana Desa Oleh Kepala Desa di wilayah Polres Wajo

\begin{tabular}{cllc}
\hline No. & $\begin{array}{l}\text { Kategori } \\
\text { Jawaban }\end{array}$ & Frekuensi & Persentase \\
\hline 1. & Berpengaruh & 28 & 56 \\
2. & $\begin{array}{l}\text { Kurang } \\
\text { berpengaruh }\end{array}$ & 17 & 34 \\
3. & $\begin{array}{l}\text { Tidak } \\
\text { berpengaruh }\end{array}$ & 5 & 10 \\
\hline & Jumlah & 50 & 100 \\
\hline
\end{tabular}

Sumber: Data primer diolah tahun 2019
Berdasarkan data pada tabel di atas menunjukkan bahwa pengaruh biaya operasional terhadap efektivitas penegakan hukum penyalahgunaan dana desa oleh kepala desa di wilayah Polres Wajo, yang menyatakan berpengaruh sebanyak 28 orang responden $(56 \%)$, yang menyatakan kurang berpengaruh sebanyak 17 orang responden (34\%), dan yang menyatakan tidak berpengaruh sebanyak 5 orang (10\%). Hal ini berarti biaya operasional berpengaruh terhadap efektivitas penegakan hukum penyalahgunaan dana desa oleh kepala desa di wilayah Polres Wajo.

Berdasarkan uraian di atas, maka dapat disimpulkan bahwa faktor substansi hukum, struktur hukum, sarana dan prasarana, budaya hukum, kesadaran hukum, dan biaya operasional berpengaruh terhadap efektifitas penegakan hukum penyalahgunaan dana desa oleh kepala desa di wilayah Polres Wajo. Oleh karena itu, keenam faktor tersebut perlu diefektifkan dengan memberdayakan secara maksimal peran dari keenam faktor tersebut di dalam menegakan hukum tindak pidana korupsi di Polres Wajo.

Faktor yang paling penting dalam dinamika korupsi adalah keadaan moral dan intelektual para pemimpin masyarakat. Keadaan moral dan intelektual dalam konfigurasi kondisi-kondisi yang lain. Beberapa faktor yang dapat menjinakkan korupsi, walaupun tidak akan memberantasnya adalah:

a. Keterikatan positif pada pemerintahan dan keterlibatan spiritual serta tugas kemajuan nasional dan publik maupun birokrasi;

b. Administrasi yang efisien serta penyesuaian structural yang layak dari mesin dan aturan pemerintah sehingga menghindari penciptaan sumber-sumber korupsi;

c. Kondisi sejarah dan sosiologis yang menguntungkan;

d. Berfungsinya suatu sistem yang antikorupsi;

e. Kepemimpinan kelompok yang berpengaruh dengan standar moral dan intelektual yang tinggi.

\section{KESIMPULAN DAN SARAN}

Hasil penelitian dan pembahasan dapat disimpulkan bahwa penegakan hukum terhadap penyalahgunaan dana desa oleh kepala desa di Wilayah Polres Wajo sudah dilaksanakan sesuai peraturan perundang-undangan yang berlaku, dimana keempat unsur Tindak Pidana Korupsi pada Pasal 2 ayat (1) subs Pasal 3 lebih subs Pasal 9 UU No. 31 tahun 1999 sebagaimana telah diubah dalam UU No. 20 tahun 2001 tentang pemberantasan Tindak Pidana Faktor substansi hukum, struktur hukum, sarana dan prasarana, budaya hukum, kesadaran hukum, dan biaya operasional berpengaruh terhadap efektifitas penegakan hukum penyalahgunaan dana desa oleh kepala desa di wilayah Polres Wajo, antara lain: substansi hukum, struktur hukum, sarana dan prasarana, budaya hukum, kesadaran hukum, dan biaya operasional.

\section{DAFTAR PUSTAKA}

Andi Hamzah, 2015. Perbandingan Pemberantasan Korupsi di berbagai Negara, Sinar Grafika, Jakarta.

Bagir Manan, 2013. Menyongsong Fajar Otonomi Daerah, Pusat Studi Hukum UII Yogyakarta, Yogyakarta.

Barda Nawawi Arief. 2012. Masalah Penegakan Hukum dan Kebijakan Hukum Menanggulangi Kejahatan. Bandung: Citra Aditya Bakti. 
Evi Hartanti, 2015. Tindak Pidana Korupsi, Sinar Grafika, Jakarta, 2009,

Gaffar Affan, 2016, Paradigma Baru Otonomi Daerah dan Implikasinya, Jakarta,Citra Aditya Bakti

Hanif Nurcholis, 2015. Teori dan Praktek Pemerintahan dan Otonomi Daerah, Grasindo, Jakarta.

Hermien Hadiati Koeswadji, 2015, Korupsi di Indonesia dari Delik Jabatan ke Tindakan Pidana Korupsi, Citra Aditya Bakti, Bandung.

Ni`matul Huda, 2015. Hukum Pemerintahan Desa Dalam Konstitusi Indonesia Sejak Kemerdekaan Hingga Era Reformasi.Setara Press, Malang.

Nur, R., Mas, M., \& Siku, A. S. (2019). Efektivitas Hukum Dalam Pelaksanaan Program Dana Desa (Dd) Dan Alokasi Dana Desa (Add) Untuk Wilayah Terpencil (Studi Kasus Di Desa Sabaru, Kecamatan Liukang Kalmas, Kabupaten Pangkep). Indonesian Journal of Legality of Law, 2(1), 23-32. https://doi.org/10.35965/ijlf.v2i1.152

Peraturan Menteri Dalam Negeri Republik Indonesia Nomor 113 Tahun 2014 tentang Pedoman Pengelolaan Keuangan Desa.

Peraturan Mentri Keuangan Republik Indonesia Nomor 241 Tahun 2014 pasal 1 tentang Pelaksanaan Pertanggungjawaban Transfer ke Daerah dan Dana Desa.

Peraturan Pemerintah Nomor 22 Tahun 2015 tentang Perubahan atas Peraturan Pemerintah Nomor 60 Tahun 2014 Tentang Dana Desa.

Peraturan Pemerintah Nomor 43 Tahun 2014 tentang Peraturan Pelaksanaan Undang-Undang No. 6 Tahun 2014 tentang Desa

Peraturan Pemerintah Nomor 47 Tahun 2015 tentang perubahan atas Peraturan Pemerintah Nomor 43 Tahun 2014 Tentang Peraturan Pelaksana Undang-Undang Desa

Permendesa Nomor 8 Tahun 2016 tentang Perubahan Nomor 21 Tahun 2015 tentang Penetapan Prioritas Penggunan Dana Desa.

Ronny Rahman Nitibaskara, 2015. Tegakkan Hukum Gunakan Hukum, Kompas, Jakarta.

Saparin, Sumber, 2017. Tata Pemerintahan dan Administrasi Pemerintahan Desa, Jakarta: Ghalia Indonesia.

Sugijanto, 2015. Beberapa Pengertian Pengawasan di Bidang Hukum, Ghalia Indonesia, Jakarta.

Undang-Undang Dasar Negara Republik Indonesia Tahun 1945, Sekretariat Jenderal MPR RI, Jakarta, 2002.

Undang-undang Nomor 23 Tahun 2014 Tentang Pemerintahan Daerah.

Undang-undang Nomor 30 Tahun 2014 Tentang Administrasi Pemerintahan Peraturan Pemerintah No. 43 Tahun 2014 Tentang Undang-undang Nomor 6 Tahun 2014 Tentang Desa.

Undang-Undang Nomor 6 Tahun 2014 tentang Desa 